\title{
Groundwater processes in a complex landslide, northern Apennines, Italy
}

\author{
F. Ronchetti ${ }^{1}$, L. Borgatti ${ }^{2}$, F. Cervi ${ }^{1}$, C. Gorgoni ${ }^{1}$, L. Piccinini ${ }^{3}$, V. Vincenzi ${ }^{3}$, and A. Corsini ${ }^{1}$ \\ ${ }^{1}$ Department of Earth Sciences, Modena and Reggio Emilia University, Modena, Italy \\ ${ }^{2}$ Department of Structural, Transport, Hydraulic, Survey and Territorial Engineering - DISTART, \\ Bologna University, Bologna, Italy \\ ${ }^{3}$ Department of Earth Sciences, Ferrara University, Ferrara, Italy
}

Received: 10 January 2009 - Revised: 4 May 2009 - Accepted: 26 May 2009 - Published: 18 June 2009

\begin{abstract}
The hydrogeological characteristics of rototranslational slides in flysch are complex, due to the inherent anisotropy and heterogeneity of rock masses and related deposits. The paper deals with the hydrogeological characterization of a reactivated roto-translational slide affecting Cretaceous flysch rocks, located in the northern Apennines of Italy. Continuous monitoring of groundwater levels, in-situ permeability and pumping tests, hydrochemical and physical analyses and Uranine tracers were the adopted prospecting methods.

In this research hydrological monitoring and investigation are summarized in order to define a hydrogeological conceptual model of the landslide source area. Results showed that two overlaying hydrogeological units exist at the slope scale: the first is unconfined, but highly compartmentalized, and hosted in the fractured and dismembered rock slide body. The second is confined and lays in the undisturbed flysch below the sliding surface. The groundwater level in the confined hydrogeological unit is twenty meters higher than the groundwater level in the uppermost one. Moreover, the groundwater chemistry characterization revealed a rising of deep fluids in the landslide area.
\end{abstract}

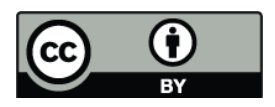

Correspondence to: F. Ronchetti (francesco.ronchetti@unimore.it)

\section{Introduction}

Previous studies on the midterm evolution of large and deep landslides have stressed that the precipitation regime itself does not completely explain the behaviour of the phenomena (Noverraz et al., 1998). In these landslides, effective infiltration, deep-water circulation patterns and the consequent increase of the hydrostatic levels and/or pore-water pressures, cumulated over long periods before the reactivation, play an important role (Hutchinson, 1970; Iverson and Major, 1987; Guglielmi et al., 2000; Cappa et al., 2004; de Montety et al., 2007). Moreover, deep fluid vents rising along tectonic structures could participate in the destabilization of slopes. Deep fluids have been detected in some landslides in northern Apennines (Bertolini and Gorgoni, 2001; Ciancabilla et al., 2004) and in other mountain chains (Bonzanigo et al., 2001).

As suggested by several Authors, groundwater circulation in deep and complex landslides cannot be easily understood by means of standard hydrological methods (Guglielmi et al., 2000; Cappa et al., 2004; de Montety et al., 2007) and the best results are gathered by means of interdisciplinary investigations.

The aim of the research is to define the origin and the flow processes of groundwater in the deep and complex $\mathrm{Ca}^{\prime}$ Lita landslide, involving heterogeneous flysch rock masses (northern Apennines), through the integration of interdisciplinary studies and expertises, including engineering geologists, geochemists and hydrogeologists.

The definition of these features in slopes affected by deep rock sliding phenomena could be of relevant interest, both for the understanding of the relationships between groundwater and landslide activity and for the design of proper drainage works. 


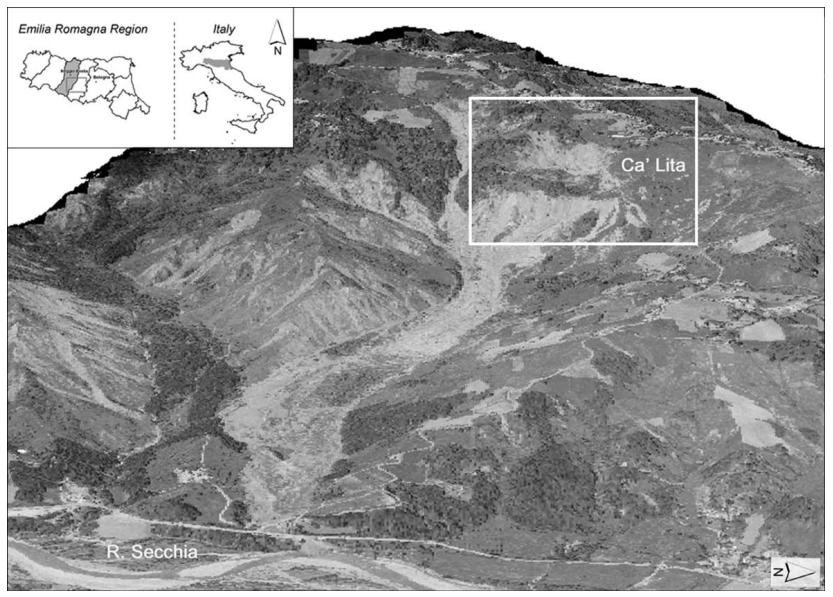

Fig. 1. Geographical location of the study site and panoramic view of the landslide in 2004. The rock slide area is marked by the white rectangle.

\section{Geological setting of the landslide area}

The Ca' Lita landslide is located in the northern Apennines of Italy, within the Secchia River basin, at an altitude ranging from about $800 \mathrm{~m}$ to $300 \mathrm{~m}$ a.s.l. (Fig. 1).

The northern Apennines are characterized by a fold-andthrust geometry that was produced after the collision of the Adria and European continental plates, starting from the Oligocene. The outcropping rock masses are mainly represented by arenitic and carbonatic flysch rock masses and mélanges (or mixtures), with an abundant or prevailing clayey component. Moreover, gypsum-anhydrite units outcrop in upper part of the watershed, few kilometres north from the study site. In all the geological units, the degree of tectonization is always intense and different sets of joints are detectable at any observation scale.

The landslide affects weak and clay-rich rock masses dating from the Upper Cretaceous to the Middle-Lower Eocene (Regione Emilia-Romagna, 1982), with a marked lithological and structural complexity that imply heterogeneity and anisotropy, both at a microscopic and macroscopic scale. The Monghidoro Flysch outcrops in the upper part of the slope. It consists of a blocky sandstone, separated by clay coated and slickensided bedding surfaces (Bieniawski, 1989; Hoek and Brown, 1997; Marinos and Hoek, 2001). The ratio between arenite and clay components is larger than 1 and the uniaxial compressive strength of the arenite is less than $60 \mathrm{MPa}$. Chaotic complexes of fine bedded clayshales and marls together with mélanges of clayshales including sandstone and limestone blocks outcrop in the intermediate and lowermost part of the slope (Val Rossenna Mélange).

An East to West high angle fault, buried by landslide deposits, divides the slope in two distinct sectors: one to the North, where flysch rock masses are dipping down slope with an upright way-up; the second to the South, where flysch rock masses are dipping upslope with overturned way-up. Moreover a North to South tectonically contact divides the flysch rock masses and the mélange (Fig. 2).

\section{Climatic setting}

This sector of the northern Apennines is characterised by annual average precipitations of about $1000 \sim 1200 \mathrm{~mm}$, distributed over 70 to 100 days. The rainfall regime shows two peaks, with the main one falling in autumn (October or November) and the secondary peak in spring (March or April). The lowest rainfall peak is recorded in summer (usually July), whereas a secondary low is in January.

The monthly mean temperature is characterized by a maximum value in July $\left(23^{\circ} \mathrm{C}\right)$ and a minimum value in January $\left(3^{\circ} \mathrm{C}\right)$. The mean annual temperature is $12.6^{\circ} \mathrm{C}$.

From a climatic standpoint, the highest amounts of yearly precipitations have been recorded for the years 2002, 2003, 2004, 2005 and 2008. On the contrary, the years 2006 and 2007 were drier, with total precipitations around one half of the mean value (Fig. 3).

Even at this relatively low elevation, some snow fall events can occur. Sometimes the snow cover melts rapidly, as a consequence of quick temperature increase at this relatively low elevation.

\section{The Ca' Lita landslide}

The geological setting of the slope controls the type of mass movements. The Ca' Lita landslide can be described as a reactivated complex roto-translational rock slide with associated earth slide and flow (WP/WLI, 1993; Cruden and Varnes, 1996) (Fig. 2).

On a first level of approximation, at least two main landslides can be traced out (Borgatti et al., 2006):

- an upper one, the rock slide, involving flysch rock masses;

- a lower one, the earth flow, involving clayey chaotic complexes.

As regards the upper one, it can be specified that in its southern part, rock sliding cuts across the flysch slab dipping upslope, and generates roto-translational movements that cause a series of trenches to develop. On the contrary, in its northernmost part, the flysch rocks dipping down slope favour the development of rather shallow translational slides over discrete strata, that, however, have not been significantly reactivated in the last years. In both parts, the resulting collapsed material is soon weathered and turned into earth masses that are involved in sliding or flowing.

As regards the lower phenomenon, it can be appreciated that its main scarp is extensively buried under the deposits deriving from the uppermost landslide, so it remains difficult 


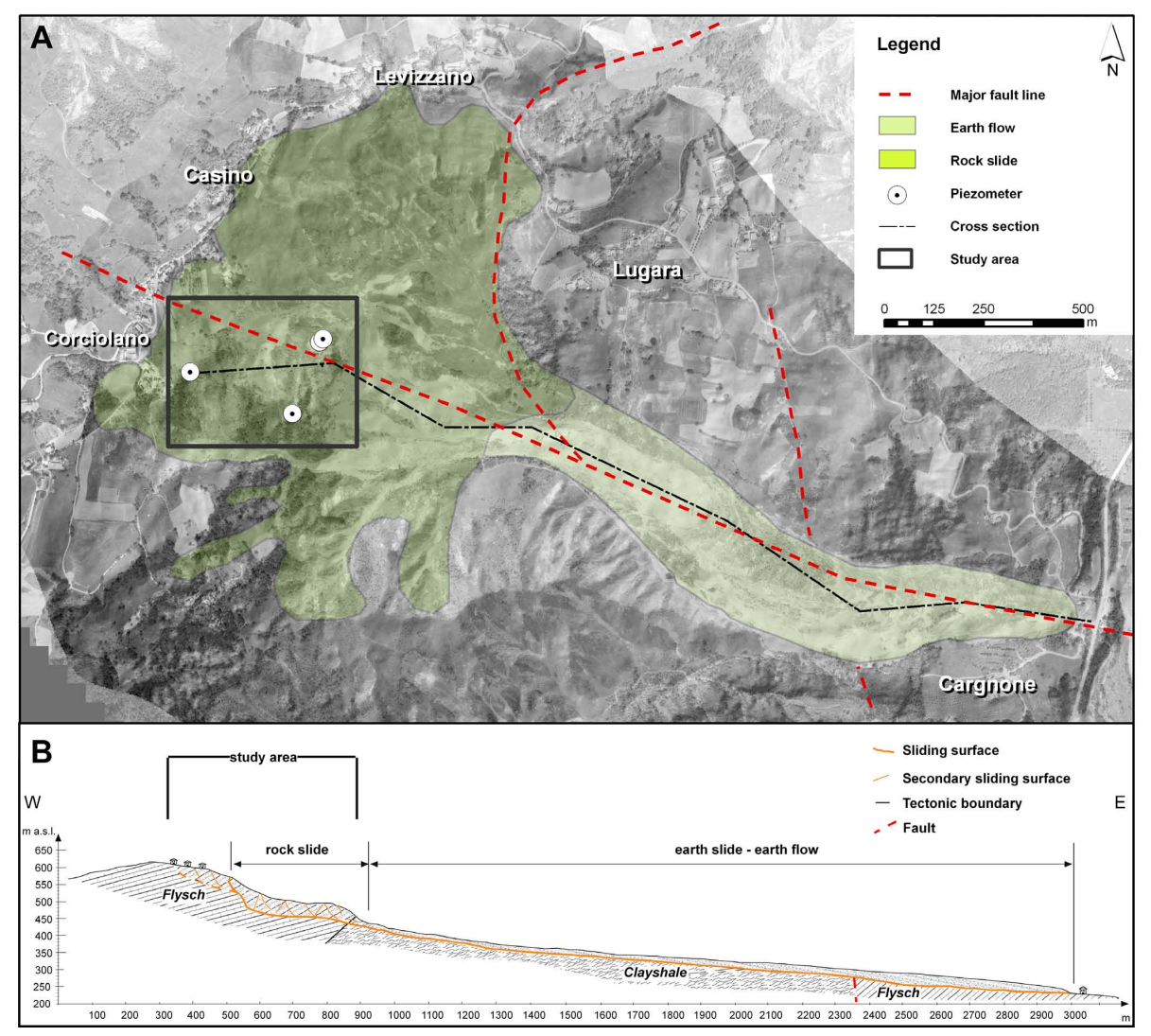

Fig. 2. Geomorphological setting of Ca' Lita landslide. (A) Geomorphological sketch. (B) Geological cross-section.

to trace it out exactly. In its upper part, the input of debris from the upper phenomenon is a relevant process. This occurs by the retrogression of the marginal portion of the sliding flysch slab.

The Ca' Lita landslide was reactivated several times in the last century. The landslide resumed activity in 2002 and underwent a surge phase by March-April 2004, when a total reactivation occurred after $150 \mathrm{~mm}$ of cumulated precipitation in two months, and following a rapid snowmelt event. From a temporal sequence viewpoint, the 2004 event was characterized by multiple and retrogressive roto-translational slides in the upper part and multiple and advancing translational slides in the middle and lower sectors of the landslide body. At that time, the failure affected an area $3 \mathrm{~km}$ long and up to $400 \mathrm{~m}$ wide, and caused the landslide toe to advance more than $400 \mathrm{~m}$ over a slope angle of about $10^{\circ}$ at velocities up to $10 \mathrm{~m} /$ day. The toe of the landslide filled the local valley with a $30 \mathrm{~m}$ thick deposit and almost reached residential housing and the main valley bottom road (Borgatti et al., 2006).

During this reactivation about twenty million cubic meters of mixed clays and boulders were mobilized (Borgatti et al., 2006). No casualties were recorded, but the magnitude of the event was such that a national road of strategic importance and socio-economic activities inside and in the vicinity of the landslide were endangered for months. This caused

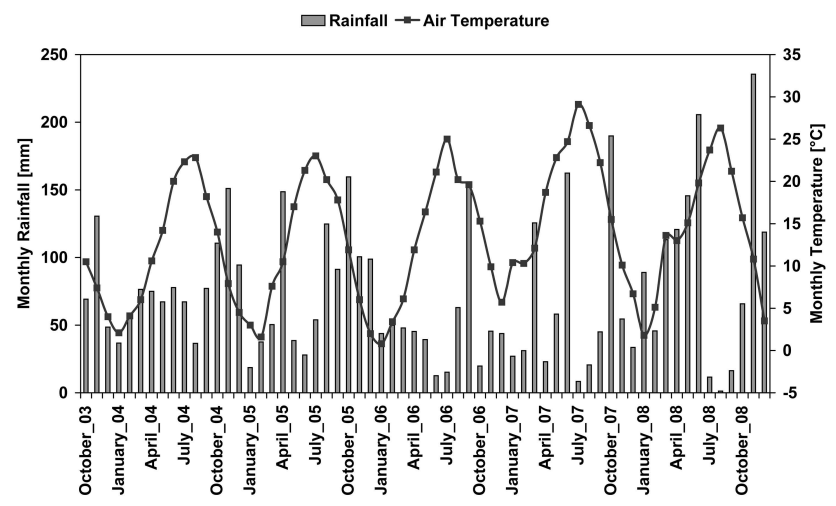

Fig. 3. Monthly rainfall and air temperature in the landslide area, from 2003 to 2008 .

a national emergency status to be issued for the affected areas. After the 2004 event, an extensive monitoring system was installed inside and around the landslide, comprising inclinometers, TDR cables and piezometers with continuous acquisition. Moreover, since 2004 a large number of countermeasure works (deep drainage wells and pile-founded retaining walls) were built in order to mitigate the risk. 


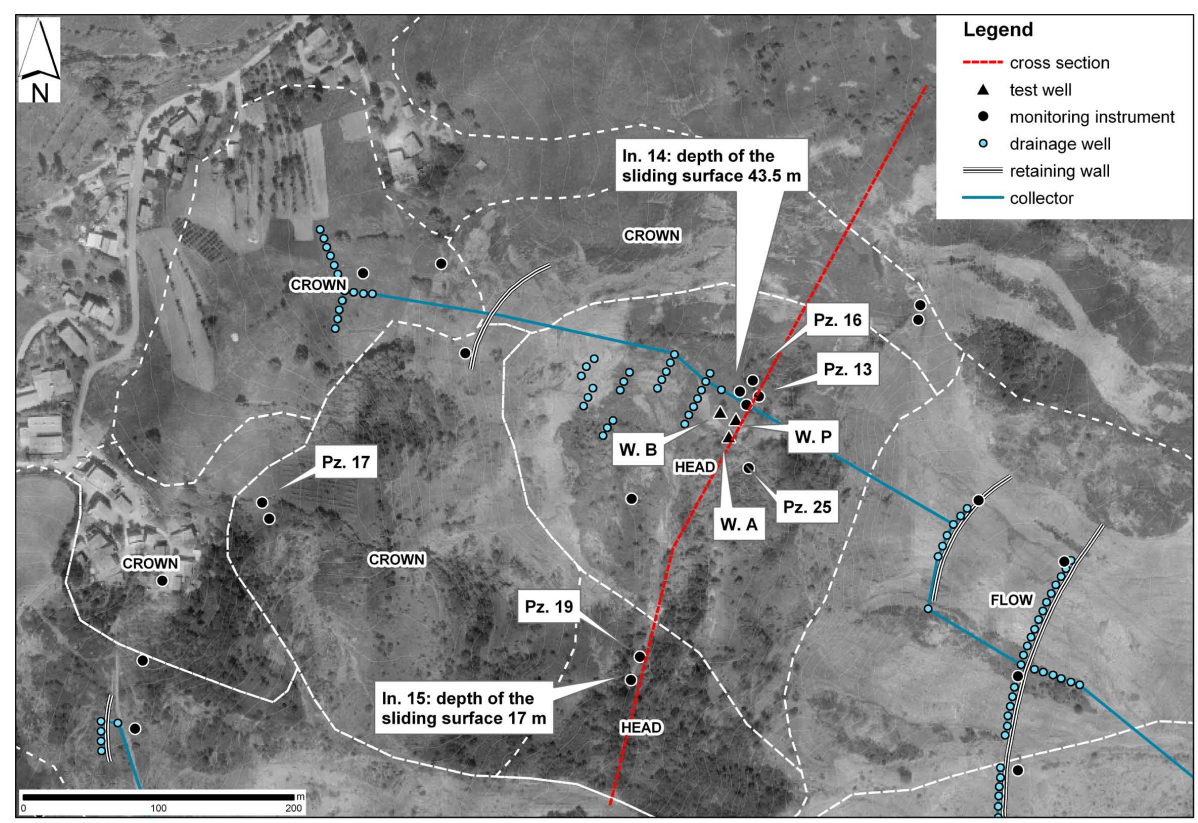

Fig. 4. Location of the geotechnical instruments and drainage systems in the rock slide area.

Most of these subsurface explorations, monitoring systems and mitigation works have been focused in upper part of the slope, where the movement takes place through retrogressive rock sliding in flysch rock masses. This area extends for about $0.5 \mathrm{~km}^{2}$ and is characterized by a marked active to dormant sliding surface at $43.5 \mathrm{~m}$ depth (Fig. 2).

In this area borehole cores showed an upper 20-30 m thick layer made up of blocks in clayey matrix, overlaying a $20 \mathrm{~m}$ thick highly fractured sandstone-rich flysch rock mass, partially disarranged by rock sliding processes. Below the sliding surface, a $30-50 \mathrm{~cm}$ thick highly fractured band, the flysch bedrock is much less fractured.

During the drilling of boreholes and of drainage wells high heterogeneity and anisotropy of both deposits and bedrock were highlighted. For instance, during the advancement of borehole drillings, at different depths, open fractures were detected together with zones with higher inflow rate. Moreover, in some cases nearby drainage wells display different equipotential groundwater head at different depths and some sub-horizontal drains, $100 \mathrm{~m}$ long at a depth of $50 \mathrm{~m}$ inside the rock slide front, are characterized by different and intermittent rate flow.

\section{Methods}

With reference to Ca' Lita landslide case study, an interdisciplinary hydrological study was performed including:

- monitoring of groundwater levels;

- parameterization of hydrogeological units;
- tracer tests;

- characterization of water chemistry.

These investigations started soon after the 2004 reactivation event and were mainly focused in the source area of the landslide, on the rock slide (Figs. 1 and 2).

The groundwater levels monitoring was performed with five standpipe piezometers, slotted at different depths both inside the landslide body and the bedrock (Table 1, Fig. 4) equipped with electric transducers and dataloggers. The monitoring started during summer 2005 and the acquisition time interval is one hour.

The hydrogeological units parameterization was conducted with nine in situ permeability tests, namely falling head test (Lefranc, 1936, 1937; Hvorslev, 1951), carried out during the borehole drillings. Moreover, a $24 \mathrm{~h}$ long pumping test has been carried out, with 6 control piezometers placed around the pumping well, with radii between 8.30 and $62 \mathrm{~m}$. The well was placed in the very centre of the head zone of the rock slide and, as the piezometers, was drilled in the landslide body (Table 2). The well and the piezometers were monitored with electrical transducers with one minute acquisition frequency during the whole test. The pumping rate was fixed at $0.25 \mathrm{l} / \mathrm{s}$.

The pumping test was performed to define the transmissivity and the storativity of the landslide body and also to assess eventual lateral connections between the different hydrogeological units located in the landslide body and in the bedrock.

The tracer test was performed with a fluorescent dye to investigate the groundwater exchange between the bedrock and 
Table 1. Characteristics of the piezometers.

\begin{tabular}{lccc}
\hline Piezometer & Slotted from-to $[\mathrm{m}]$ & Ground elevation [m a.s.l.] & Depth of sliding surface [m] \\
\hline Pz. 17 & $9-50$ & 631 & 6 \\
Pz. 13 & $50-59$ & 520 & 43.5 \\
Pz. 16 & $3-44$ & 520 & 43.5 \\
Pz. 19 & $4-59$ & 539 & 17 and 35 \\
Pz. 25 & $55-60$ & 525 & 48 \\
\hline
\end{tabular}

Table 2. Description of wells and piezometers used in the pumping test.

\begin{tabular}{lccc}
\hline Control point & Slotted from-to [m] & Ground elevation [m a.s.l.] & Distance pumping well (W. P) - piezometer [m] \\
\hline W. P & $50-59$ & 520.5 & - \\
W. A & $50-59$ & 521 & 9.00 \\
W. B & $50-59$ & 521 & 17.90 \\
Pz. 13 & $50-59$ & 520 & 8.30 \\
Pz. 16 & $3-44$ & 520 & 16.80 \\
Pz. 25 & $55-60$ & 525 & 62.00 \\
\hline
\end{tabular}

the landslide body. About $3 \mathrm{~kg}$ of Uranine were injected in a piezometer located upslope the crown zone (Pz. 17). Sampling was carried out for one year, daily in the first period and weekly afterwards, in 12 control points in the landslide, represented by piezometers, drainage wells and sub-horizontal drains (Fig. 4). The monitoring procedure required both the collection of water samples and a cumulative sampling with charcoal bags (passive adsorbing fluorescent dyes). Samples were analyzed by scanning spectrofluorimetry. A total of 37 water samples and 37 charcoal bags have been analyzed.

Water chemistry characterization was used to define the origin of the groundwater in the landslide area and to define the relation between rainfall and groundwater flow. Eight groundwater samples were collected from a number of piezometers (Pz. 13, Pz. 16, Pz. 17, Pz. 19, Pz. 25) and drainage systems (wells and collectors) inside and outside the landslide body. The sampling was carried out at different times and at different seasons, from 2006 to 2008, together with in situ measurements of $\mathrm{pH}$, electrical conductivity and temperature. Successively, the samples have been characterized both physically and chemically. In the laboratory, the concentrations of $\mathrm{K}^{+}, \mathrm{Na}^{+}, \mathrm{Cl}^{-}, \mathrm{Ca}^{2+}, \mathrm{Mg}^{2+}$, $\mathrm{SO}_{4}^{2-}$ and $\mathrm{HCO}_{3}^{-}$were measured. In addition, geophysical well loggings with electrical conductivity and temperature sensors were carried out in some piezometers. Hereafter, the most representative chemical analysis and the loggings are reported.

\section{Results}

\subsection{Monitoring of groundwater levels}

Groundwater levels in the bedrock around and underneath the landslide, as well as in the landslide body itself were recorded by electric transducers since summer 2005 with a time interval of one hour. Groundwater levels show different behaviours in time and in different landslide areas.

Groundwater levels around the landslide is monitored by means of an open pipe piezometer (Pz. 17) slotted from 9 to $50 \mathrm{~m}$ depth. It is installed in the flysch rocks making up the crown zone of the mass movement. Groundwater level variations follow closely the pattern of rainfall, with a delay between rainfall events and groundwater rise in the order of few hours up to a couple of days (Fig. 5).

Groundwater level in the landslide body is monitored by two other open-pipe piezometers (Pz. 16 and Pz. 19) that are slotted above the main sliding surface of the rock slide mass. In this uppermost hydrological unit, the properties are conditioned by the presence of open cracks and by the clay fraction spatial distribution. Groundwater variation in Pz. 16, located close to a number of deep drainage wells, is strongly controlled by the regime of electric pumping from the nearby wells. Riseing and lowering cycles correspond to the switching on and off of the pumps. The frequency of these cycles is higher during rainfall period, proving the direct link between groundwater recharge and precipitation (Fig. 6). On the contrary, being located quite far away from the drainage wells, Pz. 19 shows a groundwater level regime that is unaffected by pumping cycles. Nevertheless, the regime is also quite 


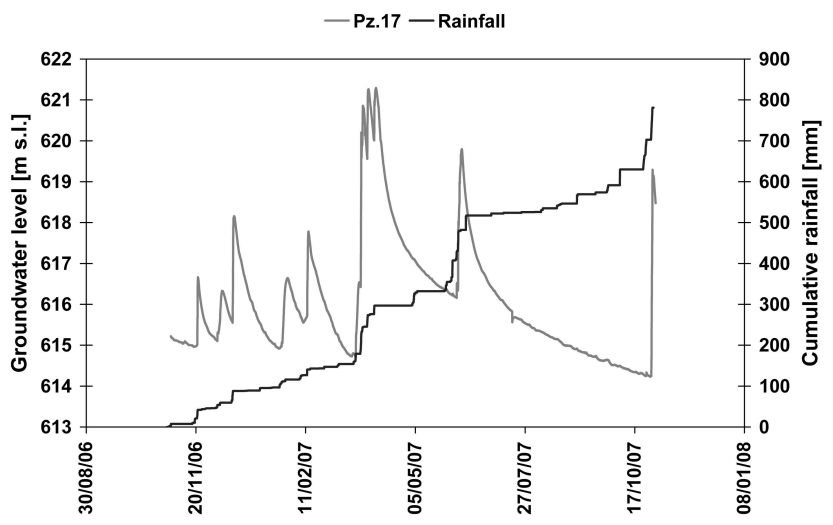

Fig. 5. Groundwater level recorded in the Pz. 17, located in the crown zone, with respect to rainfall. The data indicate a strong relationship between rainfall events and ground water rises.

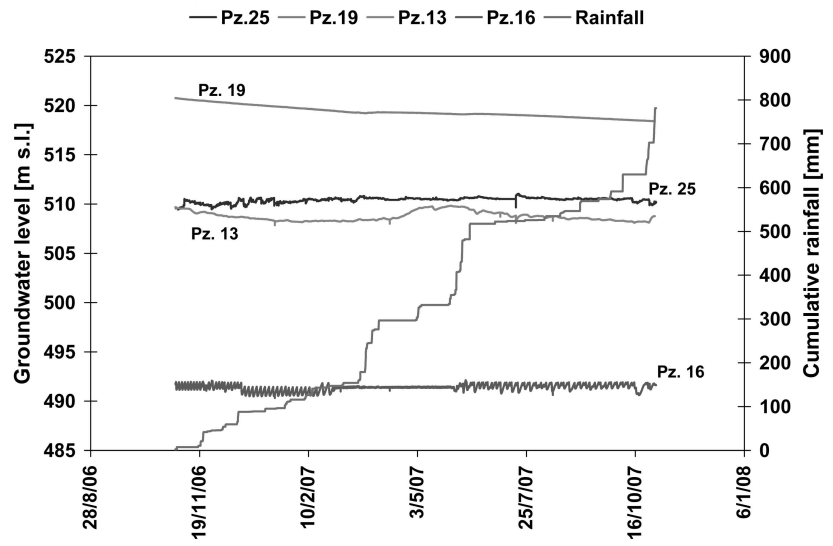

Fig. 6. Groundwater levels recorded at different piezometers (Pz. 13, Pz. 16, Pz. 19, Pz. 25) located in the head zone, with respect to rainfall. The level in Pz. 16 is affected by the pumps in the drainages works. The other piezometers do not show direct correlations between rainfall events and groundwater rises.

weakly correlated to single rainfall episodes. Level variations are smoothed, and only a seasonal trend is observed (Iverson and Major, 1987) (Fig. 6). This is probably due to the relatively higher depth of water table from the ground surface in this specific location.

Groundwater level in the bedrock underneath the landslide is monitored by Pz. 13 and Pz. 25, drilled in the head zone of the landslide, that are slotted only below the main sliding surface. Hydraulic heads are more or less $20 \mathrm{~m}$ higher than the groundwater level inside the landslide body (see level in Pz. 16), and their regime is not directly correlated with rainfall or influenced by the electric pumping (Fig. 6).

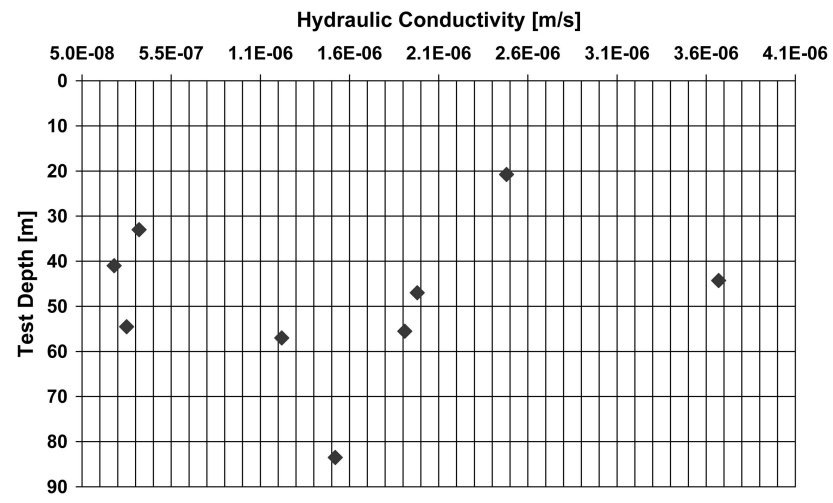

Fig. 7. Plot of the hydraulic conductivity with depth. The graph shows no correlation between hydraulic conductivity and depth and the high variability of hydraulic conductivity, linked to the fracturing of rock masses and to the amount of clay fraction.

\subsection{Parameterization of hydrogeological units}

To define the hydraulic conductivities of the hydrological units in the head and crown zone and their vertical and lateral variations, nine in situ permeability tests were carried out during the drilling of boreholes, up to $83 \mathrm{~m}$ deep. Falling head tests were carried out and the results were successively elaborated in accordance to Lefranc $(1936,1937)$ and Hvorslev (1951) theories. The hydraulic conductivity varies from $10^{-6}$ to $10^{-8} \mathrm{~m} / \mathrm{s}$ (Fig. 7).

In different boreholes, high variability of hydraulic conductivity was observed at the same depth. This is linked to the fracturing of rock masses and to the amount of clay fraction. These results are congruent with borehole logs, which show a high heterogeneity in the landslide body, both in vertical and horizontal directions. Besides, no discrepancy was found between the hydraulic conductivity in the rock slide body and in the bedrock below.

A prolonged pumping test was also performed in the head zone to assess the presence of connections between the landslide body and the bedrock and to define some hydrological properties.

The pumping test was $24 \mathrm{~h}$ long and the pumping rate was fixed at $0.25 \mathrm{l} / \mathrm{s}$. The test drained the uppermost aquifer, allowing the hydraulic interconnection between landslide deposits in the head zone to be analyzed. The test shows the development of an asymmetric depression cone in Pz. 16 and W. A, with a radius of influence larger than $40 \mathrm{~m}$ (Fig. 8).

The delay time from the starting of the test and the response of the piezometers increases with the distance wellpiezometer (Fig. 9). The first response comes from the nearest control piezometer W. A, which is $9 \mathrm{~m}$ far from W. P, and slotted at the same depth. The second response is from Pz. 16, which is $16.80 \mathrm{~m}$ far from W. P, and is slotted at a depth greater than W. P and W. A. At the same time, a 


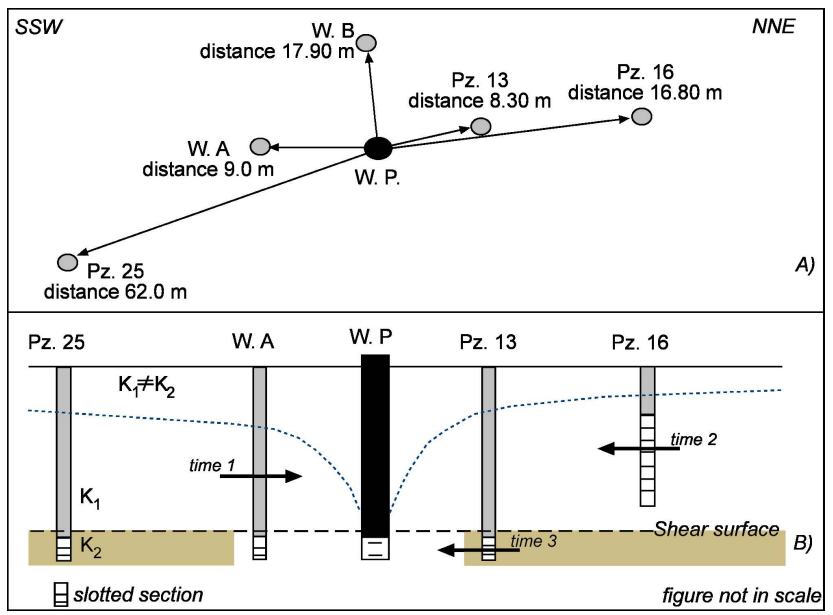

Fig. 8. Sketch of the $24 \mathrm{~h}$ long pumping test performed at Ca' Lita landslide. (A) Plan view of the pumping test area; the black circle represents the well; grey circles represent the piezometers. (B) Cross section of the pumping test area; the black arrows and respective labels represent the time response of the piezometers; the dotted cyan line represents the phreatic level; the dotted black line represents the shear surface.

delayed response is obtained in Pz. 13, that it is only $8.30 \mathrm{~m}$ far from W. P, and it is slotted at the same depth of the W. P.

This behaviour, coupled with the groundwater levels monitoring, can be interpreted by assuming the existence of different overlaying hydrologic units: an upper unconfined but highly compartmentalized unit in the fractured flysch making up the rock slide; a confined and pressurized unit in the undisturbed flysch bedrock below the sliding surface.

In a graph log drawdown - log time the behaviour of the piezometers W. A and Pz. 16 correspond with the behaviour of an unconfined aquifer with a delayed drawdown, when the effects of gravity drainage are becoming smaller (see Type B curves in Neuman, 1975). This unit is characterized by a storativity of $10^{-2}$ and a transmissivity of $4 \times 10^{-6} \mathrm{~m}^{2} / \mathrm{s}$ (Neuman, 1975).

In the end, the different time responses of the piezometers helped to build up a hydrologeological conceptual model of this sector of the landslide, composed by two hydrogeological units. The upper unit is unconfined and characterized by the direct connection between the W. P, W. A and Pz. 16. The lower one where the piezometer Pz. 13 is placed, is confined.

\subsection{Tracer test}

A tracer test with a fluorescent dye was conducted to define the groundwater exchange between the bedrock and the landslide body.

One year after the injection of Uranine in the piezometer Pz. 17, located in the crown area, no evidence of the tracer was found in the landslide. Different interpretations are possible:

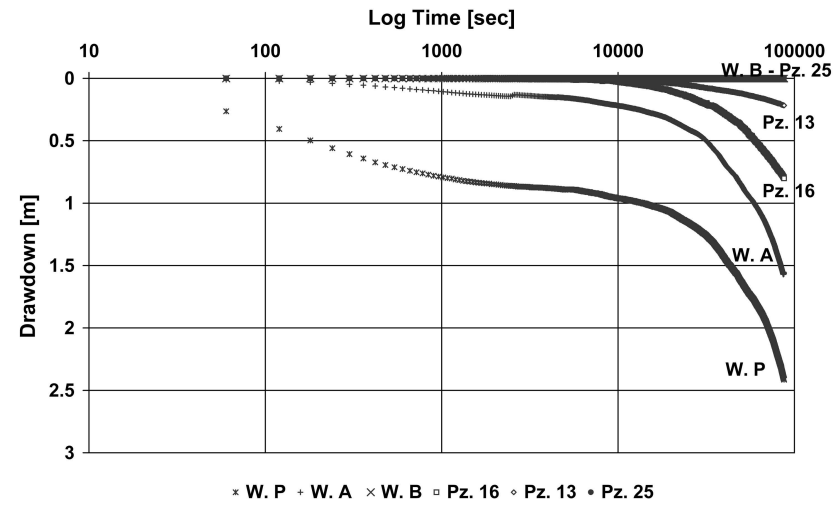

Fig. 9. Pumping test result. Drawdown in the test well and in the control points. The graph shows the direct communication between the pumped well (W. P) and the piezometers W. A and Pz. 16. The Pz. 13 shows a delayed and limited response. The Pz. 25 and W. B show no response.

1. there is no connection between the undisturbed rock mass in the crown zone and the landslide body and therefore the water circulating in the landslide body comes from direct recharge;

2. there is connection, but its determination was not possible because of the extremely low permeability $\left(<10^{-6} \mathrm{~m} / \mathrm{s}\right)$ and low effective porosity $(<5 \%)$ at the slope scale or because of high dispersion and/or dilution of the tracer in the landslide body, that made the tracer analytically not detectable.

The latter hypothesis seams the less reasonable, considering that the detection limits of Uranine are extremely low $(0.005 \mu \mathrm{g} / \mathrm{l})$ in the water and are even lower in the charcoal bags.

\subsection{Characterization of water chemistry}

Eight groundwater samples have been collected from piezometers and drainage wells inside and outside the landslide body. All samples were characterized physically and chemically. Groundwater mineralization results are reported in Table 3, while Piper diagram is in Fig. 10.

The peculiar position into the Piper diagram of groundwater sampled in Ca' Lita can be interpreted as the result of mixing between two groundwater types: Ca-carbonate rich and Na-sulfate rich. Ca-carbonate rich water is common shallow water that can be found in the Apennines chain, and is directly connected with rainfall (Minissale et al., 2000). Na-sulfate rich groundwater has being referred to, by other Authors (Minissale et al., 2000), as typical of deep-fluids flowing upward along main tectonic structures in the northern Apennines. The Na-sulfate deep fluid is characterized by cold temperature $\left(12^{\circ} \mathrm{C}\right)$ and high salinity, over $4000 \mu \mathrm{S} / \mathrm{cm}$ (Fig. 11). These Na-sulfate deep fluids are characterized, 


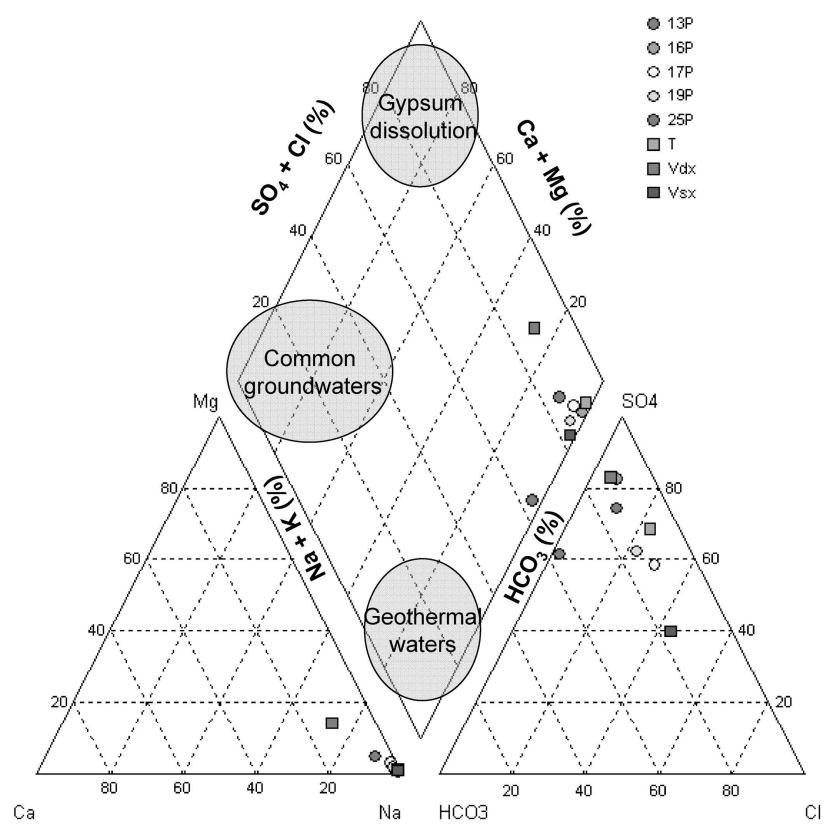

Fig. 10. Piper diagram for the collected samples. Some of the more common groundwater types in northern Apennines are displayed with shaded grey circles. Points and squares represent groundwater sampled in the landslide area.

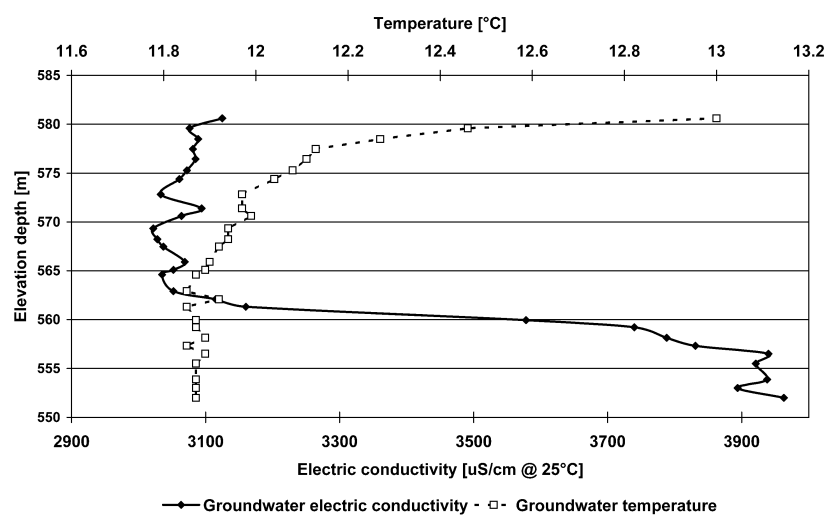

Fig. 11. Plot of groundwater electrical conductivity and temperature with depth in Pz. 17. The graph shows the presence of stratified groundwater. The deeper water shows salt enrichment.

themselves, by the mixing between two extreme hydrotypes: a Na-bicarbonate water and a Ca-sulfate water. The first is typical of geothermal water in the Apennines (Venturelli et al., 2003) and is linked to the infiltration at great depth of rain water and the subsequent long term interaction between water and rock masses that leads to degradation of the Na-silicate. The second hydrotype, Ca-sulfate water, might be related to the presence of gypsum deposits in the stratigraphic sequence of the Apennines chain (gypsum dissolution in Bertolini and Gorgoni, 2001). It might be noticed
Table 3. Mineralization in the groundwater (meq/l). Piezometers (Pz.), drainage wells collector (Vsx, Vdx, T) in Fig. 4.

\begin{tabular}{llllllll}
\hline Sample & $\mathrm{Cl}^{-}$ & $\mathrm{SO}_{4}^{2-}$ & $\mathrm{HCO}_{3}^{-}$ & $\mathrm{Ca}^{2+}$ & $\mathrm{Mg}^{2+}$ & $\mathrm{Na}^{-}$ & $\mathrm{K}^{-}$ \\
\hline Pz. 13 & 0.9 & 29.2 & 17.2 & 0.7 & 0.7 & 45.4 & 0.1 \\
Pz. 16 & 2 & 22.8 & 2.8 & 0.1 & 0.1 & 26.9 & 0.2 \\
Pz. 19 & 8.8 & 24.2 & 5.7 & 0.7 & 0.7 & 37.3 & 0.1 \\
Pz. 25 & 2.5 & 16.6 & 3.2 & 1.1 & 1.1 & 20.1 & 0.1 \\
Vsx & 22.1 & 20.4 & 8.6 & 0.5 & 0.5 & 50.2 & 0.1 \\
Vdx & 1.5 & 23.1 & 3.2 & 3.9 & 3.9 & 20.1 & 0.2 \\
$T$ & 8.5 & 25 & 2.9 & 0.4 & 0.4 & 35.5 & 0.1 \\
\hline
\end{tabular}

from the chemical characterisation that the percentage of elements varies across the landslide area, pointing to differential rates of mixing between the two water types. It can be speculated that a higher mineralization is due to a persistence of deep fluids inflow.

Another indication of the presence of stratified groundwater in the slope was derived from temperature-conductivity logging in piezometer Pz. 17, that is located in the crown zone of the landslide. It shows the abrupt increase with depth of electrical conductivity, which is proportional to the mineralization of the water (Fig. 11). The plot confirms the presence of two types of groundwater: a superficial one with a relatively low conductivity that is overlaying the second one, that displays a high conductivity. This particular behaviour can be the effect of the dilution of the deep water by the infiltration at depth of low conductivity rainfall water.

\section{Interpretation of results}

On the basis of the data collected, a schematic hydrogeological model of the source area of the $\mathrm{Ca}$ ' Lita landslide can be drawn. In this model, two overlaying hydrogeological units co-exist at the slope scale. The upper one is hosted in the landslide body, and is to be considered unconfined and compartmentalized. The lower one is hosted in the fractured flysch below the sliding surface, and is confined and pressurized (Fig. 12).

These two hydrogeological units have a markedly different response to rainfall events. Groundwater level in the upper unconfined unit mimics the pattern of rainfall, with an amplitude of groundwater fluctuations that can be metric. On the other hand, pore pressure in the confined unit shows trends which are not directly connected with precipitation events, and only smoothed and seasonal variations can be observed.

Despite the different behavior, the two units are not so differentiated in terms of permeability. Pumping and permeability tests highlighted a high variability of hydraulic conductivity, from $10^{-6}$ to $10^{-8} \mathrm{~m} / \mathrm{s}$ in both units. These spatial variations are a consequence of discontinuous fracturing of the rock masses and different clay fraction amounts in the landslide deposits or in the flysch of the bedrock. 


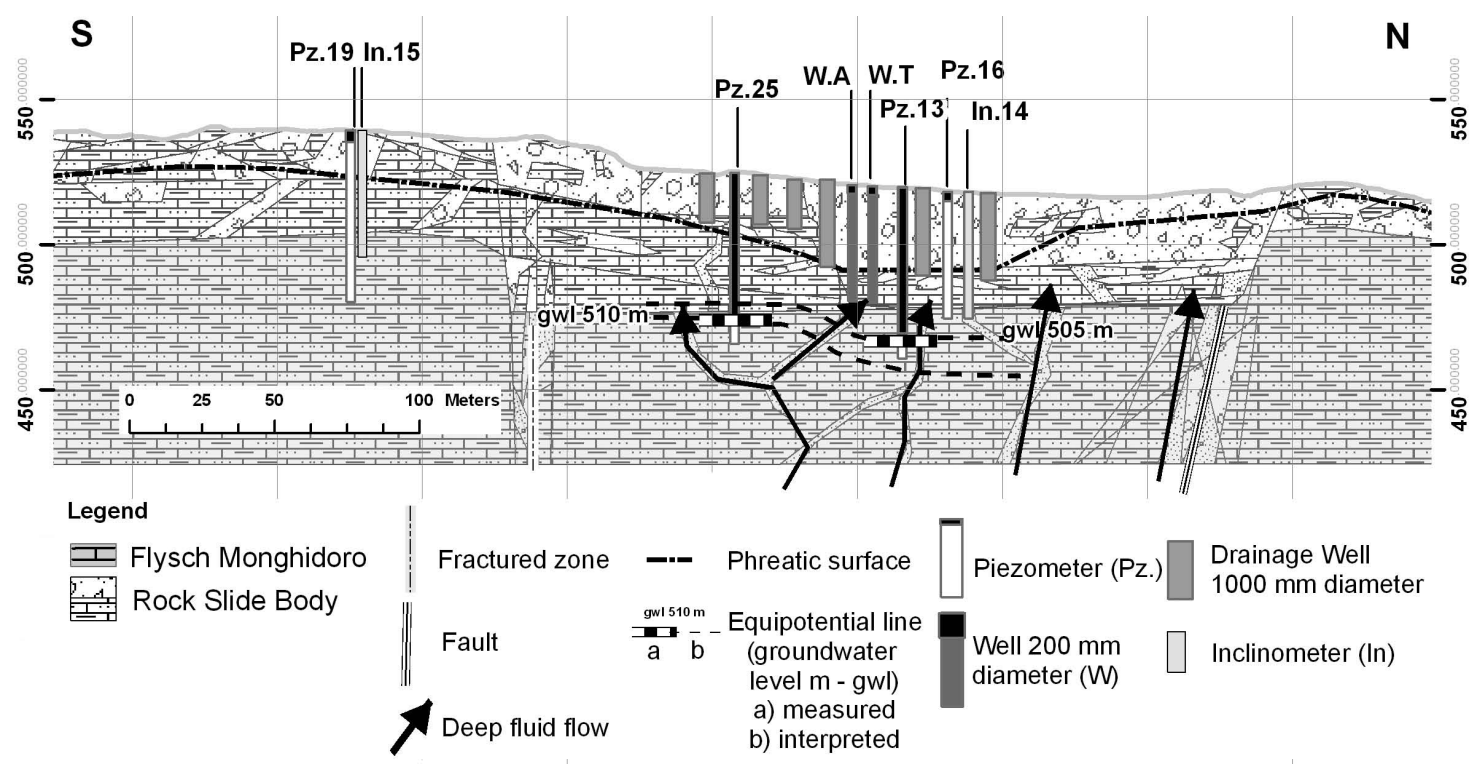

Fig. 12. Transverse hydrogeological section (track in Fig. 4) (slotted sections of piezometers in white). The cross section shows the hydrogeological conceptual model of the landslide area. Black arrows indicate deep fluids rising.

The pumping test shows also the development of a asymmetric drawdown cone in the uppermost hydrogeological unit, with a radius of influence around $40 \mathrm{~m}$. The storativity and transmissivity are respectively $10^{-2}$ and of $10^{-6} \mathrm{~m}^{2} / \mathrm{s}$.

The different time responses of the piezometers during the pumping test helped to build up the hydrologeological conceptual model. The upper unit is characterized by the direct connection between the test well (W. P) and the piezometers W. A and Pz. 16. The lower one where the piezometer Pz. 13 is placed, is characterized by low connection with the test well (W. P).

The tracer test between the undisturbed rock mass in the crown zone and 12 control points in the landslide body (wells and piezometers slotted at different depths) did not provide indications of a connection between these two sectors. Even assuming the failing of the test for high dilution/dispersion effects, if the high quantity of injected Uranine and its conservative behaviour in flysch rock masses (Vincenzi et al., 2009) are considered, it can be reasonably argued that there is no significant groundwater exchange between the two domains.

The geochemical characterization obtained by sampling and laboratory analysis highlighted that the two hydrologic units are also bearing two significantly different groundwater types. One shallow and directly connected with rainfall, that can be classified as cold and Ca-carbonate rich, with electric conductivity in the order of $800 \mu \mathrm{S} / \mathrm{cm}$. The second consists of deep fluids, rich in Na-sulfate, characterized by the mixing between the two extreme hydrotypes, Na-bicarbonate waters and Ca-sulfate waters. This deep fluids are characterized by cold temperature $\left(12^{\circ} \mathrm{C}\right)$ and high salinity, over $4000 \mu \mathrm{S} / \mathrm{cm}$.

As regards the relationships between groundwater levels and displacements during past reactivation events, some correlations were already reported in Borgatti et al. (2007). Up to now, no unambiguous correlations between the deep sliding surface and the pore pressure in the deep confined aquifer has been proved. However, further monitoring by means of in-place inclinometers, started in 2008, might lead to advancements in this topic.

\section{Conclusions}

The inherent anisotropy and heterogeneity of flysch rock masses affected by rock slides hinder the assessment of the hydrological characteristics and the groundwater flow in the slopes.

Research aims at gathering new knowledge on these issues, through hydraulic and geochemical investigations, focused on groundwater flow inside the roto-translational rockslide making up the upper part of Ca' Lita landslide (Borgatti et al., 2006). Continuous monitoring of groundwater levels, in-situ permeability and pumping tests, Uranine tracers and hydro-chemical analyses were the adopted prospecting methods.

Groundwater monitoring and hydrological parameterization in Ca' Lita show a high complexity of the hydrological units at the slope scale, that is a consequence of the high heterogeneity and anisotropy of hydraulic characteristics inside the deposits of the rock slide and in the underlying fractured bedrock. In particular, the study has highlighted that in this type of mass movement different overlaying aquifers are to be expected, and that their response to rainfall input can be 
dramatically different, in terms of timing and amplitude of fluctuations.

Moreover, the groundwater chemistry characterization revealed an inflow of deep fluids in the landslide area, which could in turn influence the long term groundwater level fluctuations underneath the landslide and, as a consequence, its stability.

These finding are nonetheless relevant for slope stabilization purposes, and proved that the draining of the sole upper unit by means of large diameter wells, as so far performed, might not assure stability in the long term, since the influence of pressurized groundwater hosted in the lowermost hydrologic unit, might be a preparing - if not triggering - factor of further large scale slope instability.

Acknowledgements. The research was partly financed in the frame of project PRIN 2007 (Integrated Airborne and Wireless Sensor Network systems for landslide monitoring - WiseLand; local responsible: A. Corsini). A large amount of data have been made available from Emilia-Romagna Region, Servizio Tecnico dei bacini degli affluenti del Po, Reggio Emilia, in the frame of a bilateral agreement. We express our gratitude T. Bogaard for constructive suggestions on an early version of the manuscript. We are also grateful to Jochen Schmidt and Alexander Remaitre for their suggestion and constructive comments on the manuscript.

Edited by: T. Glade

Reviewed by: J. Schmidt and A. Remaitre

\section{References}

Bertolini, G. and Gorgoni, C.: La Lavina di Roncovetro (Vedriano, Comune di Canossa, Provincia di Reggio Emilia, Quaderni di Geologia Applicata, 8(2), 1-21, 2001.

Bieniawski, Z. T.: Engineering rock mass classification. Wiley Interscience Publ. New York, 1989.

Bonzanigo, L., Eberhardt, E., and Loew, S.: Hydromechanical Factors Controlling the Creeping Campo Vallemaggia Landslide, Proceedings: Landslides-Causes, Impacts and Countermeasures, Davos, Switzerland, 13-22, 2001.

Borgatti, L., Cervi, F., Corsini, A., Ronchetti, F., and Pellegrini, M.: Hydromechanical mechanisms of landslide reactivation in heterogeneous rock masses of the northern Apennines (Italy), in: Proceedings of the First North American Landslide Conference, Landslides and Society: Integrated Science, Engineering; Management, and Mitigation, Vail, Colorado, June 2007, American Society of Environmental and Engineering Geologists, 2007.

Borgatti, L., Corsini, A., Barbieri, M., Sartini, G., Truffelli, G., Caputo, G., and Puglisi, C.: Large reactivated landslides in weak rock masses: a case study from the Northern Apennines (Italy), Landslides 3, 115-124, 2006.

Ciancabilla, N., Borgia, G. C., Bruni, R., Ciancabilla, F., Palmieri, S., and Vicari, L.: Le sorgenti sulfuree dell'Alta Valle del Reno (Appennino Bolognese): nuovi elementi per approfondire la genesi dei movimenti gravitativi profondi nei terreni argillitici caoticizzati dell'Appennino Tosco-Emiliano, Il Geologo dell'Emilia Romagna, 2004.
Cappa, F., Guglielmi, Y., Soukatchoff, V. M., Mudry, J., Bertrand, C., and Charmoille A.: Hydromechanical modeling of a large moving rock slope inferred from slope levelling coupled to spring long-term hydrochemical monitoring: example of the La Clapiere landslide (Southern Alps, France), J. Hydrol., 291, 6790, 2004.

Cruden, D. M. and Varnes, D. J.: Landslides Types and Processes, in: Landslides: Investigation and Mitigation Special Report, edited by: Turner, A. K. and Schuster, R. L., 247, 36-75, Washington D.C.: Transportation Research Board, National Academy Press, 1996.

De Montety, V., Marc, V., Emblanch, C., Malet, J. P., Bertrand, C., Maquaire, O., and Bogaard, T. A.: Identifying the origin of groundwater and flow processes in complex landslides affecting black marls: insights from a hydrochemical survey, Earth Surf. Process. Landforms, 32, 32-48, 2007

Guglielmi, Y., Bertrand, C., Compagnon, F., Follacci, J. P., and Mudry, J.: Acquisition of water chemistry in a mobile fissured basement massif: its role in the hydrogeological knowledge of the La Clapiere landslide (Mercantour massif, southern Alps, France), J. Hydrol., 229, 138-148, 2000.

Hoek, E. and Brown, E. T.: Practical estimates of rock mass strength, Int. J. Rock Mech. \& Mining Sci. \& Geomechanics Abstracts, 34(8), 1165-1186, 1997.

Hvorslev, M. J.: Time lag and soil permeability in ground-water observations, Vicksburg, Miss., U.S. Army Corps of Engineers, Waterways Experiment Station, Bulletin 36, 50 pp., 1951.

Hutchinson, J. N.: A coastal mudflow on the London clay cliffs at Beltinge, North Kent, Geotechnique, 24, 412-438, 1970.

Iverson, R. M. and Major, J. J.: Rainfall, groundwater flow, and seasonal motion at Minor Creek landslide, northwestern California: Physical interpretation of empirical relations, Geol. Soc. Am. Bull., 99, 579-594, 1987.

Marinos, P. and Hoek, E.: Estimating the geotechnical properties of heterogeneous rock masses such as flysch, Bull. Eng. Geol. Env., 60, 85-92, 2001.

Minissale, A., Magro, G., Martinelli, G., Vaselli, O., and Tassi, G. F.: Fluid geochemical transect in the Northern Apennines (central-northern Italy): fluid genesis and migration and tectonic implications, Tectonophysics, 319, 199-222, 2000.

Neuman, S. P.: Analysis of pumping test data from anisotropic unconfined aquifers considering delayed gravity response, Water Res. Res., 11, 329-342, 1975.

Noverraz, F., Bonnard, C., Dupraz, H., and Huguenin, L.: Grands glissements de versants et climat, Rapport final PNR 31, vdf hochschulverlag AG an der ETH Zürich, 1998.

Regione Emilia-Romagna: Carta geologica dell'Appennino emiliano-romagnolo 1: 10000 , Resp. Pignone R, Ed. SELCA, Firenze, 1982.

Venturelli, G., Boschetti, T., and Duchi, V.: Na-carbonate waters of extreme composition: Possible origin and evolution, Geochem. J., 37, 351-366, 2003.

Vincenzi, V., Gargini, A., and Goldscheider, N.: Using tracer tests and hydrological observations to evaluate effects of tunnel drainage on groundwater and surface waters in the Northern Apennines (Italy), Hydrogeol. J., 17, 135-150, 2009.

WP/WLI: Working Party on the World Landslide Inventory and Canadian Geotechnical Society, 1993, Multilingual Landslide Glossary, Richmond, B. C., BiTech Publishers, 1993. 